\title{
Synthesis and Biological Evaluation of New Salicylate Macrolactones from Anacardic Acids
}

\section{Lúcio P. L. Logrado ${ }^{a}$, Dâmaris Silveira ${ }^{b}$, Luiz A. S. Romeiro ${ }^{c}$, Manoel O. de Moraes ${ }^{d}$, Bruno C. Cavalcanti $^{d}$, Letícia V. Costa-Lotufo ${ }^{d}$, Cláudia do Ó Pessoa ${ }^{d}$ and Maria Lucilia dos Santos ${ }^{*, a}$}

${ }^{a}$ Laboratório de Isolamento e Transformação de Moléculas Orgânicas, Instituto de Química and ${ }^{b}$ Faculdade de Ciências da Saúde, Universidade de Brasília, Campus Darcy Ribeiro, 70904-970 Brasília - DF, Brazil

${ }^{c}$ Núcleo de Química Bioorgânica e Medicinal, Universidade Católica de Brasília, 71966-700 Taguatinga - DF, Brazil

${ }^{d}$ Laboratório de Oncologia Experimental, Universidade Federal do Ceará, 60431-970 Fortaleza - CE, Brazil

No âmbito de uma linha de pesquisa que visa a obtenção de novas substâncias bioativas, a partir de lipídeos fenólicos não-isoprenóides de Anacardium occidentale, descrevemos a síntese e avaliação citotóxica de novas macrolactonas salicílicas, preparadas a partir da mistura de ácidos anacárdicos, principal constituinte do líquido da casca da castanha de caju (LCC) in natura.

In connection with our ongoing investigation in the search for new bioactive compounds using non-isoprenoid phenolic lipids from Anacardium occidentale as starting material, we describe the synthesis and cytotoxicity screening of some novel salicylate macrolactones prepared from anacardic acids, the major constitutents of natural cashew nut-shell liquid (CNSL).

Keywords: cashew nut shell liquid, anacardic acids, salicylate macrolactones

\section{Introduction}

Non-isoprenoid phenolic lipids exist in plants from a number of different families, notably the Anacardiaceae shrub, many small plants, and certain bacterial sources. The cashew tree (Anacardium occidentale), a species originally native to Brazil where it is still cultivated, also grown in a large number of other tropical and sub-tropical countries, represents one of the major and cheapest sources of this class of compounds. ${ }^{1}$

As the main component of natural cashew nut-shell liquid (CNSL), anacardic acids (1) are the most widely distributed phenolic lipids. Chemically, the anacardic acids feature a convenient salicylic acid system and a long side- chain at the 6-position, in which a double bond is found at $\mathrm{C}-8$ in the monoene, diene and triene components (Figure 1). Anacardic acids are reported to exhibit a variety of biological activities, ${ }^{2}$ and also have stimulated much research in order to prepare drug analogues for application in several fields. ${ }^{3}$

In the course of ongoing investigations aiming at new drug candidates, the particular structural behavior and abundance of anacardic acids have prompted us to search for a strategy to convert these materials into analogues of an emerging family of antitumor natural products, for example: oximidines I, II, and III, ${ }^{4}$ apicularens $\mathrm{A}$ and $\mathrm{B},{ }^{5}$ and salicylhalamides A and $\mathrm{B}^{6}$ (Figure 2), which present a benzofused macrolactone bearing an unusual $\mathrm{N}$-acylated enamide<smiles>[R]c1cccc(O)c1C(=O)O</smiles>

1

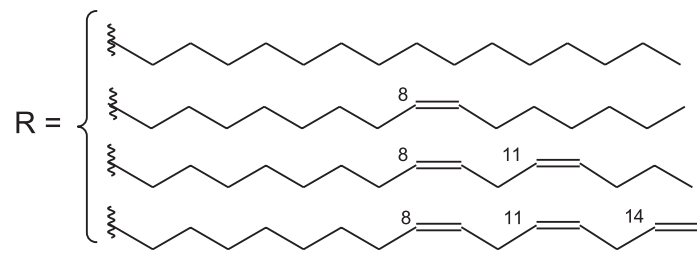

Figure 1. Anacardic acids.

* e-mail: mlsantos@unb.br 
side-chain. Related to the fact that these benzolactone enamides do not display any significant structural correlations to the profiles of known anti-cancer drugs, they constitute a very attractive new class of lead compounds in the search for antineoplastic agents and have therefore shown considerable interest concerning to isolation, chemical synthesis and mechanistic studies of the biochemical mode of action. ${ }^{4-7}$

Other macrolactones structurally related to the above macrolides include lasiodiplodin, ${ }^{8}$ cis- and transresorcylide, ${ }^{9}$ and curvularin ${ }^{10}$ (Figure 3 ). These orsellinic acid type macrolides also have attracted the attention of many synthetic chemists regarding both chemical and physiological activities. ${ }^{1-13}$ For instance, methyldehydrolasiodiplodin, a mixture of geometrical isomers used as a precursor for the synthesis of lasiodiplodin, exhibits a rather uniform in vitro activity against human tumors e.g. leukemia, lung, colon, melanoma, ovarian, renal, prostate and breast. ${ }^{14}$<smiles>CO/N=C\C=C/C(=O)N/C=C\CC(OC(=O)c1c(O)cccc1/C=C/C=C\C1OC1C)C(C)O</smiles>

Oximidine I (17 Z) Oximidine III (17 E)

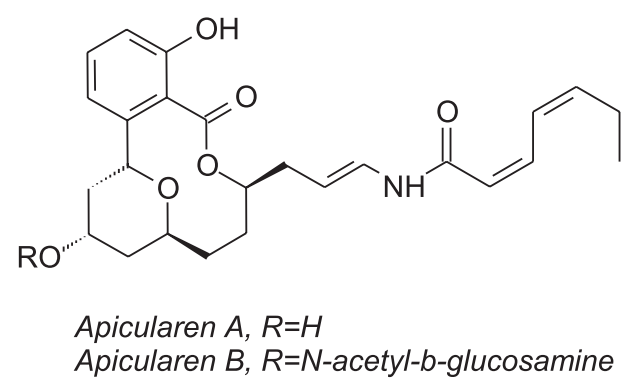

A few years ago, we reported the synthesis of lasiodiplodin from the non-isoprenoid phenolic lipids of cashew nut-shell liquid ${ }^{15}$ as well as the salicylate macrolactone 2 (Figure 4). ${ }^{16}$ Supported by the structural relationship of the compound $\mathbf{2}$ with the naturally occurring macrolides shown in Figures 2 and 3, a cytotoxicity study on this simplified analogue was initiated.

Compound 2 showed pronounced cytotoxicity in the brine shrimp lethality assay (Artemia salina). ${ }^{17}$ Since this protocol has been used to access antitumor potential in preliminary test, this result has encouraged us to prepare structural variants of macrolactone $\mathbf{2}$ in order to establish the first structure-activity relationships based on cytotoxic assays.

Herein we provide a full account of the experimental details of earlier communications ${ }^{16}$ and add new results. In particular, we report the synthetic protocols for the preparation of the salicylate macrolactone $\mathbf{2}$ and its<smiles>C/C=C\[C@@H](O)[C@H](C/C=C\NC(=O)/C=C\C=N\OC)OC(=O)c1c(O)cccc1/C=C/C=C\CO</smiles>

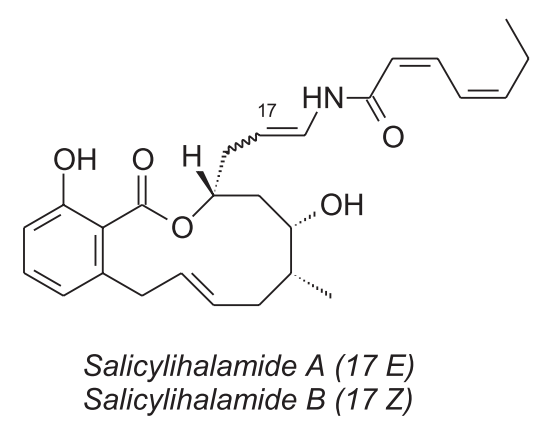

Figure 2. Benzolactone enamides.<smiles>COc1cc(O)cc2c1C(=O)OCCCCCCCC2</smiles>

Lasiodiplodin<smiles>CCCCC/C=C\Cc1cc(OC)cc(OC)c1C(=O)OC</smiles>

Methyl-dehydrolasiodiplodin<smiles>CC1CCC/C=C\C(=O)Cc2cc(O)cc(O)c2C(=O)O1</smiles>

Resorcilyde<smiles>CC1CCCCCC(=O)c2c(O)cc(O)cc2CC(=O)O1</smiles>

Curvularin

Figure 3. Orsellinic acid type macrolides.<smiles>CC(CCC/C=C/C(=O)c1c(O)cc(O)cc1CC(=O)O[Na])OC(=O)[O-]</smiles> 


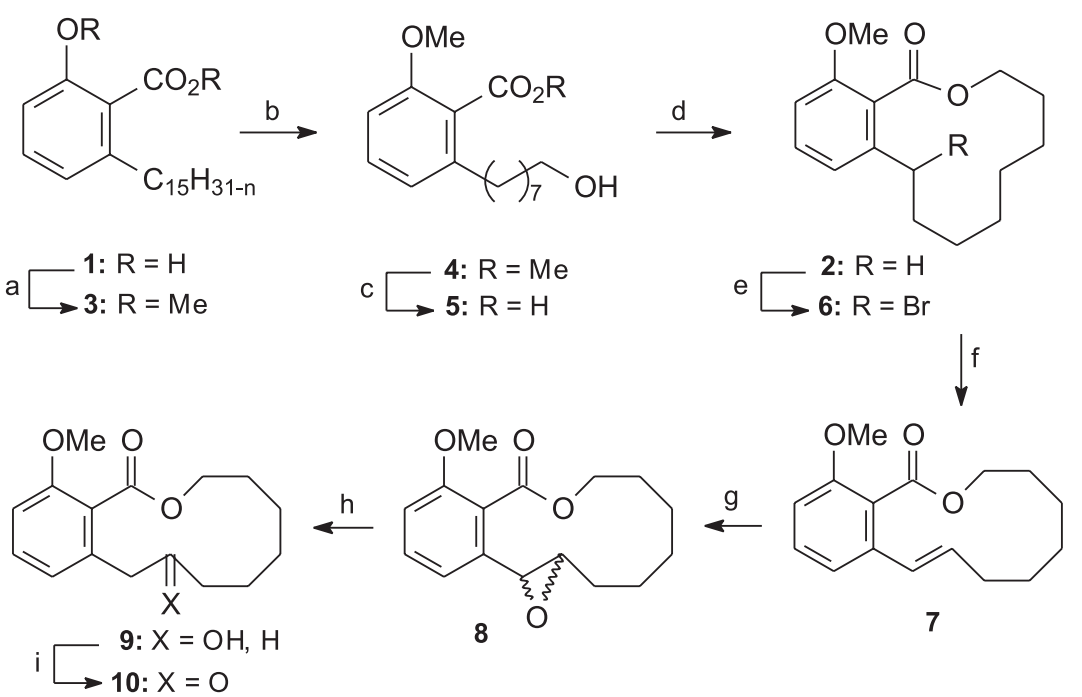

Scheme 1. Reagents and conditions: (a) $\mathrm{Me}_{2} \mathrm{SO}_{4}, \mathrm{CH}_{2} \mathrm{Cl}_{2}, \mathrm{NaOH}$, Aliquat ${ }^{\oplus}$, rt; (b) i. $\mathrm{O}_{3}, \mathrm{CH}_{2} \mathrm{Cl}_{2}, \mathrm{MeOH},-70{ }^{\circ} \mathrm{C}$; ii. $\mathrm{NaBH}_{4}$; (c) $\mathrm{KOH}_{2} \mathrm{HOCH}_{2} \mathrm{CH}_{2} \mathrm{OH}$, $165{ }^{\circ} \mathrm{C}$; (d) 2-chloro-1-methylpyridinium iodide, $\mathrm{CH}_{2} \mathrm{Cl}_{2}, \mathrm{CH}_{3} \mathrm{CN}, \mathrm{Et}_{3} \mathrm{~N}$, reflux, under nitrogen atmosphere; (e) NBS, benzoyl peroxide, PhH, reflux, under nitrogen atmosphere; (f) $\mathrm{DBU}, \mathrm{PhH}$, reflux; (g) $m$ - $\mathrm{CPBA}, \mathrm{CH}_{2} \mathrm{Cl}_{2}$, rt; (h) $\mathrm{H}_{2}, \mathrm{Pd} / \mathrm{C}, 4 \mathrm{~atm}$, rt; (i) Jones, ether, rt.

chemical transformations into related macrolides modified at either the C-13 or the C-14 positions (Figure 4, Scheme 1). Furthermore, we describe the results of the cytotoxicity screening performed on these analogues.

\section{Results and Discussion}

\section{Chemistry}

As shown in Scheme 1, our approach for the synthesis of the title compounds is an extension of a previous work involving the use of inexpensive and readily available anacardic acids (1).

The heterogeneous mixture of anacardic acids (1) was separated from fresh natural CNSL essentially by the same procedures described in the literature ${ }^{18}$ and was quantitatively converted into $\mathbf{3}$, on a multigram scale, by treatment with dimethyl sulphate under phase transfer catalysis. ${ }^{19}$ The mixture of dialkylated anacardic acids was submitted to ozonolysis, followed by reductive cleavage of the derived ozonides with sodium borohydride, furnishing the alcohol $\mathbf{4}$ in $85 \%$ yield. Hydrolysis of the ester group in $\mathbf{4}$ required rather severe conditions and was accomplished by using aqueous potassium hydroxide $\left(10 \mathrm{~mol} \mathrm{~L}^{-1}\right)$ in ethylene glycol at $165{ }^{\circ} \mathrm{C}$.

The resulting hydroxyacid $\mathbf{5}$ was converted into macrolide $\mathbf{2}$ under high dilution conditions and nitrogen atmosphere in $66 \%$ yield, employing Mukaiyama's procedure. ${ }^{20}$ The conversion of the macrolactone $\mathbf{2}$ into the analogues $\mathbf{9}$ and $\mathbf{1 0}$ commenced with benzylic bromination, according to classical conditions (NBS- benzoyl peroxide). After several attempts, we found that the bromine lactone $\mathbf{6}$ was quantitatively converted into trans-unsaturated lactone 7 by treatment with DBU in refluxing benzene under a nitrogen atmosphere.

Two distinct methods were explored toward the epoxidation of the double bond, either by treatment with performic acid or $m$-CPBA. Gratifyingly, in the latter case $\mathbf{7}$ was smoothly epoxidized to furnish $\mathbf{8}$ in $98 \%$ yield. The epoxide opening was investigated under various conditions by using heterogeneous catalytic hydrogenation in a Parr apparatus. The best result, i.e. $97 \%$, was obtained with $5 \% \mathrm{Pd}-\mathrm{C}$ in ethanol, under 4 atm of hydrogen pressure. The oxidation of the hydroxyl group in 9 was achieved by the classical Jones protocol in ether at room temperature. By means of this methodology, compound 9 was successfully converted into the keto macrolactone $\mathbf{1 0}$, in $96 \%$ yield.

The spectral properties of the all acyclic precursors and the macrocyclic lactone $\mathbf{2}$ are in accordance to the data previously reported. ${ }^{16}$ The ${ }^{1} \mathrm{H}$ and ${ }^{13} \mathrm{C}-\mathrm{NMR}$ chemical shifts of the macrocyclic lactone $\mathbf{2}$ and new analogues $\mathbf{6}$ to $\mathbf{1 0}$ were confirmed by COSY (Correlated Spectroscopy), HMQC (Heteronuclear Multiple-

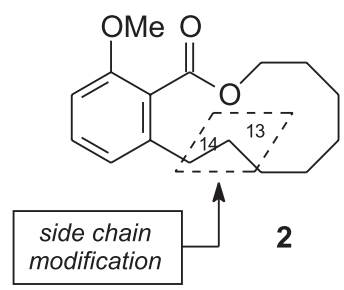

Figure 4. Simplified analogue of salicylate macrolactones. 
<smiles>[R]OC(=O)c1c([R])cccc1OC</smiles><smiles>CCCCCCCCCCCc1cccc(OC)c1C(=O)OC</smiles>

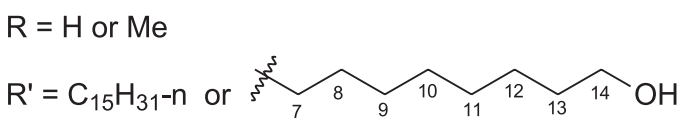

Figure 5. Numerical order of the atoms in acyclic and cyclic intermediates used for the NMR assignments.

Quantum Correlation), HMBC (Heteronuclear MultipleBond Correlation), and NOESY (Nuclear Overhauser Effect Spectroscopy). The multiplicities of the carbon signals of all compounds were determined by DEPT (Distortion-less Enhancement by Polarization Transfer) experiments. The presence of bromine in $\mathbf{6}$ was also confirmed by the quite intense $\mathrm{M}+1$ and $\mathrm{M}+2$ peaks $(\mathrm{m} / \mathrm{z}, 341$ and $343,1: 1)$ as determined by high-pressure liquid chromatography electrospray mass spectroscopy (HPLC-ESI-MS) experiments. The assignments of the ${ }^{1} \mathrm{H}$ and ${ }^{13} \mathrm{C}$ NMR peaks for the acyclic precursors and macrocyclic lactones were described according to Figure 5. These spectra data will be further explored in connection with a study underway utilizing a NMR computer-aided approach and X-ray crystallography in order to establish the conformational structure of all new macrolactones.

\section{Cytotoxicity screening}

Lethality against brine shrimp has been successfully used in order to detect antitumor and pesticidal compounds. The Artemia salina assays of the novel synthesized macrolides 2 and 6-10 were performed essentially according to Meyer's method. ${ }^{17}$ This methodology has been described as a simple, inexpensive, and convenient bioassay system, which has mostly been employed for screening of general bioactivity or as a general measure of toxicity, as well as in structureactivity relationship studies. Furthermore, it is positively correlated to $9 \mathrm{~KB}$ cell toxicity. ${ }^{21}$ Matthews suggests the use of this protocol for the discovery of compounds with ability to protect against damage by active oxygen species (AOS). ${ }^{22}$

Compounds $\mathbf{2}$ and $\mathbf{1 0}$ have been found to display significant toxicity against Artemia salina. As a matter of fact, $2\left(\mathrm{DL}_{50} 32.12 \mathrm{ppm}, 0.032 \mathrm{mg} \mathrm{mL}^{-1}\right)$ is nearly 3-times more potent than $10\left(\mathrm{DL}_{50} 98.42 \mathrm{ppm}, 0.098 \mathrm{mg} \mathrm{mL}^{-1}\right)$. The latter compound is less active than the active controls e.g. lapachol $\left(\mathrm{DL}_{50} 76.82 \mathrm{ppm}, 0.077 \mathrm{mg} \mathrm{mL}^{-1}\right)$ and potassium dichromate $\left(\mathrm{DL}_{50} 84.05 \mathrm{ppm}, 0.084 \mathrm{mg} \mathrm{mL}^{-1}\right)$. On the other hand, compounds 6-9 showed no activity detected at concentration up to $200 \mathrm{ppm}$, indicating that modification at C-13 or C-14 decreased the shrimp lethality. In light of these results, we decided to examine further the cytotocity profile of the synthesized macrolactones.

Uncontrolled proliferation is an universal property of tumor cells, thus investigation of the cellular growth control mechanism has contributed to the understanding of carcinogenesis and the discovery of compounds with specific antineoplastic activity. ${ }^{23}$ For this purpose, all of the synthesized macrolides were submitted to human tumor cell growth inhibition screening. The cytotoxic evaluation against lymphoblastic leukemia (CEM), breast cell line (MCF-7), human colon (HCT-8), and murine skin (B16), was accomplished by the MTT [3-(4,5-dimethylthiazol-2yl)-2,5-diphenyl-tetrazolium bromide] microassay described by Mosmann. ${ }^{24}$ In this method, the cell viability is determined by using a tetrazolium salt, which is reduced to a coloured product due to chemical interactions with enzymes present only in living metabolically active cells. ${ }^{25}$ Tetrazolium salts have also been used to improve detection of drug cytotoxicity in a soft agar colony formation assay ${ }^{26}$ and exhibit the advantage over many other stains of being nonlethal, allowing cells to be recovered, if desired. As shown in Table 1, the assays shown that the compounds 6 and $\mathbf{7}$ inhibited the proliferation of all four tested cell lines, $\mathbf{2}$ was active against mammalian cells, while $\mathbf{8}$ was active against HCT8 and MCF-7 cell lines.

Table 1. Cytotoxicity of compounds $\mathbf{2}$ and 6-10 based on tumor cell growth inhibition

\begin{tabular}{lcccc}
\hline \multirow{2}{*}{ Compound } & \multicolumn{4}{c}{ Cell line } \\
& \multicolumn{4}{c}{$\mathrm{CI}_{50}\left(\mu \mathrm{g} \mathrm{mL}^{-1}\right.$, confidence range $)$} \\
\cline { 2 - 5 } & $\mathrm{CEM}$ & $\mathrm{HCT}-8$ & $\mathrm{~B} 16$ & $\mathrm{MCF}-7$ \\
\hline \multirow{2}{*}{$\mathbf{2}$} & 12.45 & 7.70 & 10.53 \\
& $8.59-18.03$ & $6.31-9.57$ & $>25$ & $9.63-11.51$ \\
$\mathbf{6}$ & 12.48 & 9.01 & 16.76 & 9.96 \\
& $5.5-21.09$ & $5.86-13.86$ & $11.73-23.96$ & $7.09-13.99$ \\
$\mathbf{7}$ & 11.13 & 11.0 & 11.8 & 4.32 \\
$\mathbf{8}$ & $7.91-15-49$ & $8.81-13.7$ & $1.11-125.0$ & $3.47-5.37$ \\
$\mathbf{9}$ & & 14.78 & & 14.52 \\
$\mathbf{1 0}$ & $>25$ & $9.78-22.33$ & $>25$ & $11.62-18.14$ \\
& $>25$ & $>25$ & $>25$ & $>25$ \\
Doxorubicin & $0.01-0.02$ & $0.03-0.05$ & $0.02-0.04$ & $0.17-0.24$ \\
\hline
\end{tabular}

${ }^{a}$ Positive control. 


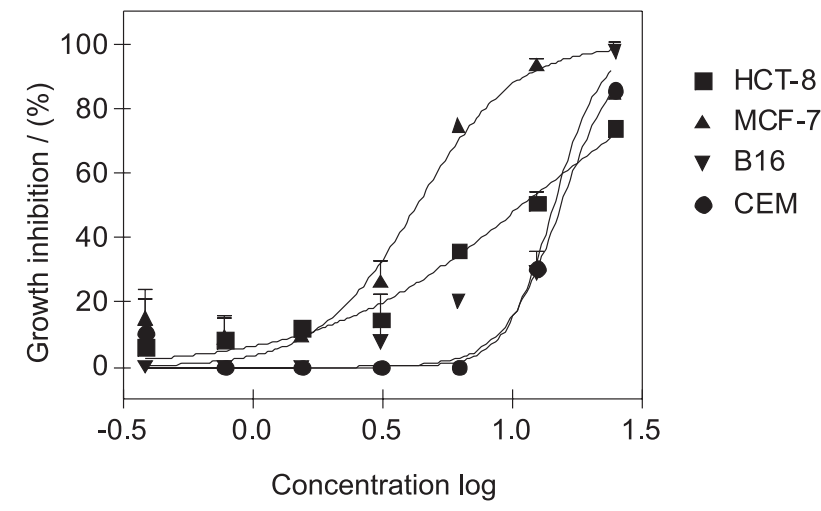

Figure 6. Growth inhibition of the compound $\mathbf{7}$ against tumor cell lines.

Interestingly, the macrolactone 7 exhibited unique differential ex vivo activity against MCF-7 cells (Figure 6). These findings suggest that the double bond at the benzylic position may play an important role in assisting its cytotoxic profile, as in the truncated macrolides oximidines. Pure compounds could be considered satisfactory to warrant further studies as an antineoplastic drug when they present an $\mathrm{IC}_{50}$ values lower than $1 \mu \mathrm{g} \mathrm{mL}^{-1}$ or $1 \mu \mathrm{mol} \mathrm{L}^{-1} .{ }^{27}$ Efforts to expand the investigation around $\mathbf{7}$ are currently underway and will be reported in due course.

In order to verify whether the active substances acted through membrane disruption, all the new chemical entities (2 and 6-10) were tested for the ability to induce lysis in mouse erythrocytes. ${ }^{28}$ The results showed that none of them cause membrane damage.

\section{Experimental}

\section{Instrumentation, chemical and solvents}

The oxidative cleavages were performed with a Welsbach T-408 ozonizator and the catalytic hydrogenations in a Parr apparatus. Flash Column Chromatography and Dry-Column Flash Chromatography were carried out using silica gel Merck $60 \AA$ (70-230 mesh) and eluting with a gradient of hexane:ethyl acetate. Analytical thin layer chromatography was performed on precoated Merck silica gel $\left(60 \mathrm{~F}_{254} / 0.2 \mathrm{~mm}\right)$ plates using UV light, 5\% ethanolic phosphomolybdic acid or iodine vapours to visualize the spots. Melting points were obtained on a Köffler apparatus and are uncorrected. IR-FT spectra were recorded on a Bomem Hartmann \& Braun (MB - 100) spectrometer. ${ }^{1} \mathrm{H}$ and ${ }^{13} \mathrm{C}-\mathrm{NMR}$ were recorded on Mercury plus Varian (7.05 T) and Bruker (17.60 T) spectrometers, using $\mathrm{CDCl}_{3} / \mathrm{TMS}$. ${ }^{1} \mathrm{H}$ and ${ }^{13} \mathrm{C}$ chemical shifts are reported in parts per million (ppm) relative to TMS. High pressure liquid chromatography electrospray mass spectroscopy
(HPLC-ESIMS) experiments were performed using a Quattro II Micromass/Waters spectrometer.

\section{Isolation of anacardic acids (1)}

The shells $(500 \mathrm{~g})$ of cashew nuts from Anacardium occidentale (Ceará, Brazil) were extracted in a Soxhlet extractor with commercial 95\% ethanol $(2.0 \mathrm{~L})$ during $6 \mathrm{~h}$, yielding a crude extract (CNSL, $157 \mathrm{~g}, 31 \%$ by weight). Anacardic acids (1) were removed in $61 \%$ from CNSL $(15.25 \mathrm{~g})$ either by precipitation with lead nitrate or calcium hydroxide. ${ }^{18}$ The spectral properties were identical to those reported in the literature. ${ }^{29}$

\section{Methyl anacardate methyl ethers (3)}

A $500 \mathrm{~mL}$ three necked round-bottom flask fitted with a mechanical stirrer was charged with anacardic acids (15 $\mathrm{g}, 43 \mathrm{mmol}$, average molecular wt 358), dichloromethane $(200 \mathrm{~mL}), 3 \mathrm{~mol} \mathrm{~L}^{-1}$ sodium hydroxide solution $(60 \mathrm{~mL})$ and Aliquat ${ }^{\circledR} 336$ (1.7 g, $\left.10 \mathrm{~mol} \%\right)$. To this mixture was added dimethyl sulphate $(20 \mathrm{~mL} ; 215 \mathrm{mmol})$. After $2 \mathrm{~h}$, at room temperature, a cloudy emulsion initially formed became a clear two-phase mixture to which was added 100 $\mathrm{mL}$ of a $2 \mathrm{~mol} \mathrm{~L}^{-1}$ ammonium hydroxide solution. After stirring for $30 \mathrm{~min}$ at room temperature, the organic phase was washed with water $(3 \times 50 \mathrm{~mL})$, brine $(2 \times 50 \mathrm{~mL})$, and dried over sodium sulphate. Evaporation of the solvent furnished a brown residue which was chromatographed on silica gel (hexane-ethyl acetate, 9:1) to give $3^{19}$ as a colourless oil (14.3 g; 95\%). IR (film) $v_{\max } / \mathrm{cm}^{-1}: 3008$, 2927, 2855, 1735, 1585, 1470, 1432, 1268. ' $\mathrm{H}$ NMR (300 $\left.\mathrm{MHz}, \mathrm{CDCl}_{3}\right) \delta: 7.26$ (t, $\left.J 8.40 \mathrm{~Hz}, 1 \mathrm{H}, \mathrm{ArH}-4\right), 6.82(\mathrm{~d}, J$ $7.8 \mathrm{~Hz}, \mathrm{ArH}-5), 6.77$ (d, J 8.7 Hz, ArH-3), 5.88-5.75 (m, $=\mathrm{CH}), 5.46-5.28(\mathrm{~m},=\mathrm{CH}), 5.08-4.95(\mathrm{~m},=\mathrm{CH}), 3.90(\mathrm{~s}$, $\left.\mathrm{COOCH}_{3}\right), 3,81\left(\mathrm{~s}, \mathrm{OCH}_{3}\right), 2.90-2.70\left(\mathrm{~m},=\mathrm{CCH}_{2} \mathrm{C}=\right), 2.76-$ 2.50 (deformed t, $\left.J 8.0 \mathrm{~Hz}, \mathrm{CH}_{2}-7\right), 2.06-1.98(\mathrm{~m}, J 8.0 \mathrm{~Hz}$, $\left.\mathrm{CH}_{2}-7\right), 1.62-1.53\left(\mathrm{~m}, \mathrm{CH}_{2}\right), 1.38-1.23$ (br, aliphatic sidechain $\mathrm{CH}_{2}$ ), 0.88 (deformed t, $J 7.0 \mathrm{~Hz}, \mathrm{CH}_{3}$ ). ${ }^{13} \mathrm{C}$ NMR $(75$ $\left.\mathrm{MHz}, \mathrm{CDCl}_{3}\right): 168.88\left(\underline{\mathrm{COOCH}}_{3}\right), 156.18$ (C-2), 141.26 (C-6), 130.31 (C-4), 130.17-114.28 (olefinic region), 123.40 (C-1), 121.42 (C-5), 108.28 (C-3), $55.78\left(\mathrm{ArOCH}_{3}\right)$, $55.05\left(\mathrm{COOCH}_{3}\right), 33.41-22.60$ (aliphatic side-chain), 14.06 (terminal $\mathrm{CH}_{3}, \mathrm{n}=0$ ).

\section{Methyl-2-methoxy-6-(8-hydroxyoctyl) benzoate (4)}

A solution of $3(3.0 \mathrm{~g}, 8.00 \mathrm{mmol}$ average molecular wt $376)$ in dichloromethane $(75 \mathrm{~mL})$ and methanol $(75 \mathrm{~mL})$ at $70^{\circ} \mathrm{C}$ was treated with ozone until the reaction was shown to be complete by thin layer chromatography (hexane-ethyl 
acetate, 9:1). The reaction mixture was purged with nitrogen, an excess of sodium borohydride $(2.0 \mathrm{~g})$ was added, and the resulting mixture was stirred at room temperature overnight. After addition of water $(10 \mathrm{~mL})$, the reaction mixture was hydrolysed with $10 \%$ hydrochloric acid $(20 \mathrm{~mL})$ and then extracted with ethyl acetate $(3 \times 30 \mathrm{~mL})$. The combined extracts were washed with brine $(3 \times 30 \mathrm{~mL})$, dried over sodium sulphate and evaporated. The residue was chromatographed on silica gel (hexane-ethyl acetate, $2: 1$ ) to afford the pure alcohol $4^{16}$ as a solid $\left(1.88 \mathrm{~g} ; 79 \%, \mathrm{mp} 108-109^{\circ} \mathrm{C}\right)$. IR (KBr) $v_{\max } / \mathrm{cm}^{-1}:$ 3400, 2931, 1734, 1600, 1470, 1268, 1268, 1075. ${ }^{1} \mathrm{H}$ NMR (300 MHz, $\left.\mathrm{CDCl}_{3}\right) \delta: 7.24$ (t, J 8.2 Hz, $\left.1 \mathrm{H}, \mathrm{ArH}-4\right)$, 6.79 (d, J 8.2 Hz, 1 H, ArH-5), 6.73 (d, J 8.2 Hz, 1H, ArH-3), $3.88\left(\mathrm{~s}, \mathrm{COOCH}_{3}\right), 3.79$ (s, $\left.\mathrm{ArOC}_{3}\right), 3.59$ (t, J $6.5 \mathrm{~Hz}, 2 \mathrm{H}$, $\left.\mathrm{CH}_{2}-14\right), 2.51$ (dt, J 7.54 Hz, $\left.2 \mathrm{H}, \mathrm{CH}_{2}-7\right), 1.60$ (m, $2 \mathrm{H}, \mathrm{CH}_{2}-$ 8), 1.50 (m, $\left.2 \mathrm{H}, \mathrm{CH}_{2}-13\right), 1.40$ (m, $\left.2 \mathrm{H}, \mathrm{CH}_{2}-12\right), 1.28(\mathrm{~m}, 6 \mathrm{H}$, $\mathrm{CH}_{2}-9$ to 11$) .{ }^{13} \mathrm{CNMR}\left(75 \mathrm{MHz}, \mathrm{CDCl}_{3}\right) \delta: 168.92\left(\mathrm{COOCH}_{3}\right)$, 156.11 (C-2), 141.16 (C-6), 130.17 (C-4), 123.20 (C-1), 121.36 (C-5), 108.25 (C-3), 62.76 (C-14), $55.73\left(\mathrm{ArOC}_{3}\right), 52.06$ $\left(\mathrm{COOCH}{ }_{3}\right), 33.32$ (C-7), 32.59 (C-13), 30.97 (C-8), 29.24 (C9), 29.21 (C-10), 29.14 (C-11), 25.57 (C-12).

\section{2-Methoxy-6-(8-hydroxyoctyl) benzoic acid (5)}

To a solution of the hydroxyester $4(1.37 \mathrm{~g}, 4.60 \mathrm{mmol})$ in ethylene glycol $(30 \mathrm{~mL})$ was added a $10 \mathrm{~mol} \mathrm{~L}^{-1}$ potassium hydroxide solution $(3.5 \mathrm{~mL})$. After stirring at $165{ }^{\circ} \mathrm{C}$ for $1 \mathrm{~h}$ under an argon atmosphere, the reaction mixture was acidified with $10 \%$ hydrochloric acid $(15 \mathrm{~mL})$ and then extracted with ethyl acetate $(3 \times 30 \mathrm{~mL})$. The combined extracts were washed with brine $(3 \times 30 \mathrm{~mL})$, dried over sodium sulphate and evaporated. The pure acid $5^{16}$ was obtained as a white solid by recrystalization from hexane-ethyl acetate (1.04 g, 80\%; mp 102-103 $\left.{ }^{\circ} \mathrm{C}\right)$. IR $(\mathrm{KBr}) v_{\max } / \mathrm{cm}^{-1}: 3400,2927,1695,1580,1473,1270 .{ }^{1} \mathrm{H}$ NMR (300 MHz, $\left.\mathrm{CDCl}_{3}\right) \delta: 7.26$ (dd, J7.6 Hz, $\left.1 \mathrm{H}, \mathrm{ArH}-4\right)$, 6.85 (d, J 8.4 Hz, 1 H, ArH-5), 6.83 (d, J7.6 Hz, 1 H, ArH-3), 3.79 (s, $3 \mathrm{H}, \mathrm{OCH}_{3}$ ), 3.52 (t, J6.3 Hz, $2 \mathrm{H}, \mathrm{CH}_{2}-14$ ), 2.90 (br, $1 \mathrm{H}, \mathrm{OH}), 2.60-2.50$ (t, J 7.3 Hz, $\left.2 \mathrm{H}, \mathrm{CH}_{2}-7\right), 1.58$ (m, $2 \mathrm{H}$, $\left.\mathrm{CH}_{2}-8\right), 1.48$ (m, $2 \mathrm{H}, \mathrm{CH}_{2}-13$ ), 1.40-1.38 (br, $8 \mathrm{H}, \mathrm{CH}_{2}-9$ to12). ${ }^{13} \mathrm{C} \mathrm{NMR}\left(75 \mathrm{MHz}, \mathrm{CDCl}_{3}-\mathrm{CD}_{3} \mathrm{COCD}_{3}\right) \delta: 168.51$ (COOH), 155.41 (C-2), 140.37 (C-6), 129.27 (C-4), 123.20 (C-1), 120.87 (C-5), 107.72 (C-3), 61.44 (C-14), 54.96 $\left(\mathrm{OCH}_{3}\right), 32.70(\mathrm{C}-7), 31.94(\mathrm{C}-13), 30.43(\mathrm{C}-8), 28.72(\mathrm{C}-$ 10), 28.58 (C-9), 28.45 (C-11), 25.00 (C-12).

\section{4-Methoxy-7,8,9,10,11,12,14-octahydro-6-oxa-benzo- cyclododecen-5-one (2)}

To a refluxing solution of 2-chloro-1-methylpyridinium iodide $(0.84 \mathrm{~g}, 3.28 \mathrm{mmol})$ in dichloromethane
$(50 \mathrm{~mL})$ and acetonitrile $(17 \mathrm{~mL})$ was continuously and uniformly added a solution of hydroxyacid 5 (0.20 g, 0.7 $\mathrm{mmol})$ and triethylamine $(0.78 \mathrm{~mL}, 5.6 \mathrm{mmol})$ in dichloromethane $(50 \mathrm{~mL})$ over a period of $10 \mathrm{~h}$, under a nitrogen atmosphere. After addition, the reaction mixture was refluxed for an additional $2 \mathrm{~h}$. The solvent was removed under reduced pressure and the residue was dissolved in ethyl acetate $(30 \mathrm{~mL})$, washed with water $(10 \mathrm{~mL})$, diluted phosphoric acid solution (10 $\mathrm{mL})$, saturated sodium bicarbonate solution $(10 \mathrm{~mL})$, brine $(2 \times 20 \mathrm{~mL})$ and dried over sodium sulphate. The organic phase was concentrated to give a pale yellow residue, which was chromatographed on silica gel (hexane-ethyl acetate, 9:1) to afford 2 as a white solid $\left[0.124 \mathrm{~g}, 66 \%, \mathrm{mp} 58-60{ }^{\circ} \mathrm{C}\right]$. IR $(\mathrm{KBr}) v_{\max } / \mathrm{cm}^{-1}$ : 2929, 2857, 1727, 1598, 1584, 1470, 1437, 1264. ${ }^{1} \mathrm{H}$ NMR $\left(500 \mathrm{MHz} \mathrm{CDCl}_{3}\right) \delta: 6.84(\mathrm{~d}, J 7.6 \mathrm{~Hz}, 1 \mathrm{H}, \mathrm{ArH}-1), 7.28$ (t, $J 8.0 \mathrm{~Hz}, 1 \mathrm{H}, \mathrm{ArH}-2), 6.76$ (d, J 8.3 Hz, $1 \mathrm{H}, \mathrm{ArH}-3), 4.45$ (t, $\left.J 5.3,2 \mathrm{H}, \mathrm{CH}_{2}-7\right), 3.83$ (s, $3 \mathrm{H}, \mathrm{OCH}_{3}$ ), 2.59 (t, J 7.5 Hz, $2 \mathrm{H}$, $\left.\mathrm{CH}_{2}-14\right), 1.89$ (m, $\left.2 \mathrm{H}, \mathrm{CH}_{2}-8\right), 1.60$ (m, $\left.2 \mathrm{H}, \mathrm{CH}_{2}-9\right), 1.71$ (m, $\left.2 \mathrm{H}, \mathrm{CH}_{2}-13\right), 1.49$ (m, $\left.2 \mathrm{H}, \mathrm{CH}_{2}-10\right), 1.41$ (m, $2 \mathrm{H}, \mathrm{CH}_{2}-$ 11), 1.43-1.36 (m, $\left.2 \mathrm{H}, \mathrm{CH}_{2}-12\right) .{ }^{13} \mathrm{C} \mathrm{NMR}(125 \mathrm{MHz}$, $\left.\mathrm{CDCl}_{3}\right) \delta: 169.19(\mathrm{C}-5), 156.40$ (C-4), 141.76 (C-14a), 130.47 (C-2), 124.93 (C-1), 122.18 (C-3), 108.55 (C-4a), $67.10(\mathrm{C}-7), 56.26\left(\mathrm{OCH}_{3}\right), 30.67$ (C-14), 30.33 (C-8), 26.85 (C-10), 26.41 (C-11), 26.11 (C-12), 25.27 (C-9), 24.22 (C13). HR-ESIMS $\mathrm{m} / \mathrm{z}[\mathrm{M}+\mathrm{H}]^{+}$found 263.0739. Calc. for $\mathrm{C}_{16} \mathrm{H}_{23} \mathrm{O}_{3}: 263.1647$.

14-Bromo-4-methoxy-7,8,9,10,11,12,13,14-octahydro-6oxa-benzocyclododecen-5-one (6)

A mixture of the lactone $2(0.74 \mathrm{~g}, 2.80 \mathrm{mmol})$, NBS $(0.60 \mathrm{~g}, 2.80 \mathrm{mmol})$ and benzoyl peroxide (catalytic amount) in benzene $(30 \mathrm{~mL})$ was refluxed for $4 \mathrm{~h}$, under an argon atmosphere. The resultant brown mixture was filtered trough a glass-fritted funnel. Water $(10 \mathrm{~mL})$ was added to the filtrate and then extracted with ethyl acetate $(3 \times 20 \mathrm{~mL})$. The combined organic extracts was washed with saturated sodium bicarbonate solution $(20 \mathrm{~mL})$, brine (2 x $20 \mathrm{~mL})$, and dried over sodium sulphate. The organic phase was concentrated to furnish a yellow solid, which was recrystallized from hexane-ethyl acetate to afford bromide 6 as white crystals $\left(0.960 \mathrm{~g}, 100 \%\right.$, mp $\left.116^{\circ} \mathrm{C}\right)$. IR (KBr) $v_{\max } / \mathrm{cm}^{-1}: 2932,2856,1730,1599,1593,1472,1437 .{ }^{1} \mathrm{H}$ NMR (500 MHz, $\left.\mathrm{CDCl}_{3}\right) \delta: 7.29(\mathrm{~d}, J 7.6 \mathrm{~Hz}, \mathrm{ArH}-1), 7.40$ (t, $J 8.1 \mathrm{~Hz}, 1 \mathrm{H}, \mathrm{ArH}-2), 6.84$ (d, J 8.2 Hz, $1 \mathrm{H}, \mathrm{ArH}-3), 5.05$ (m, $1 \mathrm{H}, \mathrm{CH}-14$ ), 4,99 (m, $\left.1 \mathrm{H}, \mathrm{CH}_{2}-7\right), 3.96$ (dt, J 11.15 and 1.84 $\mathrm{Hz}, 1 \mathrm{H}, \mathrm{CH}_{2}-7^{\prime}$ ) , 3.84 (s, $3 \mathrm{H}, \mathrm{OCH}_{3}$ ), 2.18 (br, $1 \mathrm{H}, \mathrm{CH}_{2}-8$ ), 1.73 (br, 1 H, $\mathrm{CH}_{2}-8$ ') 1.73 (br, $2 \mathrm{H}, \mathrm{CH}_{2}-12$ ), 1.49-1.35 (m, 6 $\mathrm{H}, \mathrm{CH}_{2}-9$ to 11$) .{ }^{13} \mathrm{C} \mathrm{NMR}\left(125 \mathrm{MHz}, \mathrm{CDCl}_{3}\right) \delta: 167.56(\mathrm{C}-$ 5), 155.82 (C-4), 141.27 (C-14a), 131.29 (C-2), 122.64 (C- 
1), 121.29 (C-3), 110.56 (C-4a), 67.89 (C-7), $56.43\left(\mathrm{OCH}_{3}\right)$, 49.3 (C-14), 39.55 (C-13), 26.69 (C-8), 26.07 (C-10), 26.53 (C-9), 25.07 (C-12), 23.77 (C-11). HR-ESIMS $\mathrm{m} / z$ [M+H] $]^{+}$ found 341.3620. Calc. for $\mathrm{C}_{16} \mathrm{H}_{22} \mathrm{BrO}_{3}: 341.0752$.

4-Methoxy-7,8,9,10,11,12-hexahydro-6-oxa-benzocyclododec-13-en-5-one (7)

To a solution of bromide $6(1.22 \mathrm{~g}, 3.56 \mathrm{mmol})$ in benzene ( $30 \mathrm{~mL})$, DBU $(2.7 \mathrm{~mL}, 17.8 \mathrm{mmol})$ was added. After stirring under reflux and an argon atmosphere for 10 $\mathrm{h}$, the reaction mixture was quenched with $10 \%$ hydrochloric acid $(15 \mathrm{~mL})$ and then extracted with ethyl acetate $(3 \times 20 \mathrm{~mL})$. The combined organic extracts were washed with $10 \%$ hydrochloric acid $(20 \mathrm{~mL})$, brine $(2 \times 20 \mathrm{~mL})$, and dried over sodium sulphate. The organic phase was concentrated to furnish a yellow solid, which was recrystallized from hexane-ethyl acetate to afford the transunsaturated lactone 7 as white crystals $(0.86 \mathrm{~g}, 94 \%, \mathrm{mp}$ $\left.79-80{ }^{\circ} \mathrm{C}\right)$. IR (KBr) $v_{\max } / \mathrm{cm}^{-1}: 2929,2864,1720,1595$, 1572, 1472, 1438, 1258, 1119, 1108, 1071. ' $\mathrm{H}$ NMR (500 $\left.\mathrm{MHz}, \mathrm{CDCl}_{3}\right) \delta: 7.40$ (t, J 8.1 Hz, $\left.1 \mathrm{H}, \mathrm{ArH}-2\right), 6.90$ (d, J 7.7 $\mathrm{Hz}, 1 \mathrm{H}, \mathrm{ArH}-1), 6.82$ (d, $J 8.3 \mathrm{~Hz}, 1 \mathrm{H}, \mathrm{ArH}-3), 6.42$ (d, $J$ $15.8,1 \mathrm{H}, \mathrm{CH}-14), 5.88$ (dt, $J 15.8$ and $7.3 \mathrm{~Hz}, 1 \mathrm{H}, \mathrm{CH}-13$ ), 4.37 (t, J $\left.5.5 \mathrm{~Hz}, 2 \mathrm{H}, \mathrm{CH}_{2}-7\right), 3.85$ (s, $\left.3 \mathrm{H}, \mathrm{OCH}_{3}\right), 2.18$ (m, $\left.2 \mathrm{H}, \mathrm{CH}_{2}-12\right), 1.75\left(\mathrm{~m}, 2 \mathrm{H}, \mathrm{CH}_{2}-8\right), 1.57-1.40\left(\mathrm{~m}, 6 \mathrm{H}, \mathrm{CH}_{2}-\right.$ 9 to 11$).{ }^{13} \mathrm{C}$ NMR (125 MHz, $\left.\mathrm{CDCl}_{3}\right) \delta: 168.44$ (C-5), 156.73 (C-4), 138.85 (C-13), 138.55 (C-14a), 130.96 (C2), 129.26 (C-14), 122.44 (C-4a), 119.95 (C-1), 109.70 (C3), $66.04(\mathrm{C}-7), 56.32\left(\mathrm{OCH}_{3}\right), 32.73(\mathrm{C}-12), 27.57(\mathrm{C}-10)$, 26.61 (C-8), 25.15 (C-11), 23.99 (C-9). HR-ESIMS m/z $[\mathrm{M}+\mathrm{H}]^{+}$found 261.2289. Calc. for $\mathrm{C}_{16} \mathrm{H}_{21} \mathrm{O}_{3}: 261.1490$.

\section{4-Methoxy-3,11-dioxa-tricyclo[11.4.0.0 $\left.0^{2,4}\right]$ heptadeca-} 1(17),13,15-trien-12-one (8)

To a solution of unsaturated lactone $7(0.10 \mathrm{~g}, 0.38$ $\mathrm{mmol})$ in dichloromethane $(2 \mathrm{~mL})$ was added drop wise a solution of $m$-CPBA $(0.13 \mathrm{~g}, 2.0 \mathrm{eq})$ in dichloromethane $(2 \mathrm{~mL})$. The reaction mixture was stirred for $4 \mathrm{~h}$, and then diluted with ethyl acetate $(20 \mathrm{~mL})$. The organic phase was washed with saturated sodium bicarbonate solution (10 $\mathrm{mL})$, brine $(2 \times 10 \mathrm{~mL})$, and dried over sodium sulphate. The organic phase was concentrated to give a yellow solid, which was recrystallized from hexane-ethyl acetate to afford epoxide $\mathbf{8}$ as white crystals $(0.09 \mathrm{~g}, 98 \%$, mp 128$\left.129^{\circ} \mathrm{C}\right)$. IR (KBr) $v_{\max } / \mathrm{cm}^{-1}: 2958,2922,2849,1728,1600$, $1472,1444,1379,1262 .{ }^{1} \mathrm{H}$ NMR $\left(500 \mathrm{MHz}, \mathrm{CDCl}_{3}\right) \delta$ : 7.35 (t, J 8.1 Hz, $1 \mathrm{H}, \mathrm{ArH}-2), 6.90$ (d, J 8.3 Hz, $1 \mathrm{H}, \mathrm{ArH}-3$ ), $6.83(\mathrm{~d}, J 7.8,1 \mathrm{H}, \mathrm{ArH}-1), 4.28(\mathrm{dt}, J 11.0$ and $3.2 \mathrm{~Hz}, 1 \mathrm{H}$, $\left.\mathrm{CH}_{2}-7\right), 4.55$ (td, $J 11.2$ and $\left.2.8 \mathrm{~Hz}, 1 \mathrm{H}, \mathrm{CH}_{2}-7\right), 3.86$ (s, 3
$\mathrm{H}, \mathrm{OCH}_{3}$ ), 3.59 (d, J $\left.1.3 \mathrm{~Hz}, 1 \mathrm{H}, \mathrm{CH}-14\right), 2.71$ (dd, J 7.9 and 1.9, $1 \mathrm{H}, \mathrm{CH}-13), 2.18$ (d, $\left.J 12.0 \mathrm{~Hz}, 1 \mathrm{H}, \mathrm{CH}_{2}-12\right)$, 1.89-1.64 (m, $8 \mathrm{H}, \mathrm{CH}_{2}-10$ to 13$), 1.56-1.36\left(\mathrm{~m}, 1 \mathrm{H}, \mathrm{CH}_{2}-\right.$ 12). ${ }^{13} \mathrm{C}$ NMR (125 MHz, $\mathrm{CDCl}_{3}$ ) $\delta: 167.57$ (C-5), 156.77 (C-14a), 137.59 (C-4), 131.58 (C-2), 122.95 (C-4a), 116.04 (C-1), 110.87 (C-3), 68.53 (C-7), 64.32 (C-13), 57.91 (C14), $56.41\left(\mathrm{OCH}_{3}\right), 29.53$ (C-12), 28.27-24.80 (C-8 to C11). HR-ESIMS $m / z,[\mathrm{M}+\mathrm{H}]^{+}$found 277.1451. Calc. for $\mathrm{C}_{16} \mathrm{H}_{21} \mathrm{O}_{4}: 277.1440$.

13-Hydroxy-4-methoxy-7,8,9,10,11,12,13,14-octahydro-6oxa-benzocyclododecen-5-one (9)

To a solution of epoxide $8(0.10 \mathrm{~g}, 0.36 \mathrm{mmol})$ in absolute ethanol $(5 \mathrm{~mL})$ was added $5 \%$ palladium on carbon $(0.03 \mathrm{~g}, 0.04 \mathrm{eq})$. The mixture was shaker in a Parr apparatus, under hydrogen atmosphere (4 atm) until the reaction was shown to be complete by TLC (hexane-ethyl acetate, 2:1). After $2 \mathrm{~h}$, the reaction mixture was filtered over Celite $\AA$. The filtrate was concentrated under reduced pressure and the yellow residue was flash chromatographed on silica gel (hexane-ethyl acetate, 4:1) to give the pure alcohol 9 as white crystals $\left(0.98 \mathrm{~g}, 97 \%\right.$, mp 109-110 $\left.{ }^{\circ} \mathrm{C}\right)$. IR (KBr) $v_{\max } / \mathrm{cm}^{-1}: 3487,3411,2956,2853,1721,1702$, 1598, 1585, 1472, 1438, 1267, 1296. 'H NMR (500 MHz, $\left.\mathrm{CDCl}_{3}\right) \delta: 7.30(\mathrm{~d}, J 8.1 \mathrm{~Hz}, 1 \mathrm{H}, \mathrm{ArH}-2), 6.95(\mathrm{~d}, J 7.6 \mathrm{~Hz}$, 1H, ArH-1), 6.83 (d, J $8.3 \mathrm{~Hz}, 1 \mathrm{H}, \mathrm{ArH}-3), 4.73$ (m, $1 \mathrm{H}$, $\mathrm{CH}_{2}-7$ ), 4.14 (td, $J 11.2$ and $2.1 \mathrm{~Hz}, 1 \mathrm{H}, \mathrm{CH}-7$ '), 3.96 (m, $1 \mathrm{H}, \mathrm{CH}-13), 3.83$ (s, $3 \mathrm{H}, \mathrm{OCH}_{3}$ ), 3.00 (dd, $J 13.9$ and 3.9 $\mathrm{Hz}, 1 \mathrm{H}, \mathrm{CH}_{2}-14$ ), 2,54 (dd, $J 13.9$ and $7.21 \mathrm{~Hz}, 1 \mathrm{H}, \mathrm{CH}_{2}-$ 14 '), 1.79 (m, 2H, $\left.\mathrm{CH}_{2}-12\right), 1.64-1.41$ (m, $8 \mathrm{H}, \mathrm{CH}_{2}-8$ to 11). ${ }^{13} \mathrm{C}$ NMR (125 MHz, $\left.\mathrm{CDCl}_{3}\right) \delta$ : $169.01(\mathrm{C}-5), 156.86(\mathrm{C}-$ 4), 137.67 (C-14a), 130.46 (C-2), 125.04 (C-1), 123.36 (C3), 109.50 (C-4a), 72.59 (C-13), $67.40(\mathrm{C}-7), 56.34\left(\mathrm{OCH}_{3}\right)$, 38.98 (C-14), 35.54-22.25 (C-8 to C-12). HR-ESIMS m/z $[\mathrm{M}+\mathrm{H}]^{+}$found 279.2295. Calc. for $\mathrm{C}_{16} \mathrm{H}_{23} \mathrm{O}_{4}: 279.1596$.

14-Methoxy-7,8,9,10,11,12-hexahydro-14H-6-oxabenzocyclododecene-5,13-dione (10)

To a solution of alcohol $6(0.10 \mathrm{~g}, 0.36 \mathrm{mmol})$ in ether $(3 \mathrm{~mL}$ ) was added Jones reagent $(2.7 \mathrm{~mL})$. After stirring for $1 \mathrm{~h}$, the reaction mixture was quenched with ethanol (about $0.5 \mathrm{~mL})$, diluted with brine $(10 \mathrm{~mL})$ and then extracted with ethyl acetate $(3 \times 10 \mathrm{~mL})$. The combined organic extracts were washed with brine $(3 \times 10 \mathrm{~mL})$, and dried over sodium sulphate. The organic phase was concentrated to give a yellow residue which was flash chromatographed on silica gel (hexane-ethyl acetate, 4:1) affording the pure keto lactone $\mathbf{1 0}$ as white crystals (97 mg, 96\%, mp 91-92 $\left.{ }^{\circ} \mathrm{C}\right)$. IR (KBr) $v_{\max } / \mathrm{cm}^{-1}: 2946,2861,1721,1587,1473$, 
1438, 1332, 1297, 1267, 1194, 1123. ${ }^{1} \mathrm{H}$ NMR $(500 \mathrm{MHz}$ $\left.\mathrm{CDCl}_{3}\right) \delta: 7.33(\mathrm{t}, J 7.9 \mathrm{~Hz}, 1 \mathrm{H}, \mathrm{ArH}-2), 6.86(\mathrm{~d}, J 8.4 \mathrm{~Hz}, 1$ $\mathrm{H}, \mathrm{ArH}-3), 6.80(\mathrm{~d}, J 7.6 \mathrm{~Hz}, 1 \mathrm{H}, \mathrm{ArH}-1), 4.41(\mathrm{t}, J 5.0 \mathrm{~Hz}, 2$ $\left.\mathrm{H}, \mathrm{CH}_{2}-7\right), 3.83$ (s, $\left.2 \mathrm{H}, \mathrm{CH}_{2}-14\right), 3.82$ (s, $\left.3 \mathrm{H}, \mathrm{OCH}_{3}\right), 2.47$ (t, J $\left.6.2 \mathrm{~Hz}, 2 \mathrm{H}, \mathrm{CH}_{2}-12\right), 1.79\left(\mathrm{~m}, 2 \mathrm{H}, \mathrm{CH}_{2}-11\right), 1.76(\mathrm{~m}$, $\left.2 \mathrm{H}, \mathrm{CH}_{2}-8\right), 1.50$ (m, $\left.2 \mathrm{H}, \mathrm{CH}_{2}-9\right), 1.46\left(\mathrm{~m}, 2 \mathrm{H}, \mathrm{CH}_{2}-10\right)$. ${ }^{13} \mathrm{C}$ NMR (125 MHz, $\mathrm{CDCl}_{3}$ ) $\delta: 208.22$ (C-13), 168.42 (C5), 156.89 (C-4), 132.74 (C-14a), 130.70 (C-2), 124.72 (C3), $124.11(\mathrm{C}-1), 110.24$ (C-4a), $66.54(\mathrm{C}-7), 56.3\left(\mathrm{OCH}_{3}\right)$, 46.83 (C-14), 42.25 (C-12), 27.14 (C-8), 24.94 (C-10), 23.67 (C-9), $23.41(\mathrm{C}-11)$. HR-ESIMS $m / z[\mathrm{M}+\mathrm{H}]^{+}$found 277.2076. Calc. for $\mathrm{C}_{16} \mathrm{H}_{21} \mathrm{O}_{4}: 277.1440$.

\section{Cytotoxicity assays}

Brine shrimp lethality assay. Brine shrimp Artemia salina encysted eggs (Maramar) were incubated in simulated seawater at $28^{\circ} \mathrm{C}$ during $48 \mathrm{~h}$ with artificial light. The samples were dissolved in $200 \mu \mathrm{L}$ of DMSO plus 20 $\mu \mathrm{L}$ of artificial seawater. Serial dilutions (triplicate) were prepared from the same solution. Metanauplii (10 units) was added to each set of tubes containing the samples and the cultures were incubated for additional $24 \mathrm{~h}$. Controls containing DMSO were included in each set of experiments. Lapachol and potassium dichromate were used as reference standards. LC $_{50}$ (after $24 \mathrm{~h}$ ) were calculated by Probit analysis.

Tumor cell growth inhibition assays. Adherent cells $\left(0.2 \times 10^{5}\right.$ cell $\left.100 \mu \mathrm{L}^{-1}\right)$ and suspension cells $\left(0.5 \times 10^{6}\right.$ cells $100 \mu \mathrm{L}^{-1}$ ) were seeded in 96 well microplates (Nucnck) and pre-incubated for $24 \mathrm{~h}$ in order to allow cell attachment. For the suspension cells this is not necessary. After plating the cells, fresh medium $(100 \mu \mathrm{L})$ containing various concentrations $\left(0.39\right.$ and $\left.25 \mathrm{mg} \mathrm{mL}^{-1}\right)$ of the samples was added to the cultures, then the cells were incubated for 72 h. Cell survival was evaluated by adding MTT tetrazolium salt solution with fresh medium. Doxorubicin (Doxolem ${ }^{\circledR}$, Zodiac Produtos Farmacêuticos S/A, Brazil) was used as positive control. After $3 \mathrm{~h}$ incubation at $37{ }^{\circ} \mathrm{C}, 150 \mu \mathrm{L}$ of DMSO was added to dissolve the precipitate of reduced MTT. Microplates were then shaken for $15 \mathrm{~min}$, and the absorbance was determined at $550 \mathrm{~nm}$ with a multiwell scanning spectrophotometer. CEM (human acute lymphoblastic leukemia), MCF-7 (breast cell line), HCT-8 (human colon) and B16 (murine skin) were maintained in RPMI 1640 (Gibco BRL), containing 10\% fetal bovine serum (FBS; Gibco BRL), $1 \%$ penicillin and streptomycin solution (Life Technologies), and incubated at $37{ }^{\circ} \mathrm{C}$ in $5 \% \mathrm{CO}_{2}$ atmosphere.
Hemolytic assay. The test was performed in 96-well plates. Each well received $100 \mu \mathrm{L}$ of $0.85 \%$ saline containing $10 \mathrm{mmol} \mathrm{L}^{-1}$ calcium chloride solution. The first well was the negative control that contained only the vehicle (DMSO 10\%) and, in the second well, $50 \mu \mathrm{L}$ of the test sample and $50 \mu \mathrm{L}$ of brine were added. The compounds were tested at concentrations ranging from 0.39 to $200 \mu \mathrm{g}$ $\mathrm{mL}^{-1}$. The serial dilution continued until the $11^{\text {th }}$ well. The last well received $20 \mu \mathrm{L}$ of $0.1 \%$ triton $\mathrm{X}-100$ (in $0.85 \%$ saline) to obtain $100 \%$ hemolysis (positive control). Then, each well received $100 \mu \mathrm{L}$ of a $2 \%$ suspension of mouse erythrocytes in $0.85 \%$ saline containing $10 \mathrm{mmol} \mathrm{L}^{-1}$ calcium chloride solution. After incubation at room temperature for $30 \mathrm{~min}$ and centrifugation, the supernatant was removed and the liberated hemoglobin was measured spectroscopically as absorbance at $540 \mathrm{~nm}$.

\section{Acknowledgments}

Financial support from CNPq and FINEP (Process CTINFRA 970/2001, 1040091/2004 and contract 01.04.0091.00), Universidade de Brasília, Universidade Federal do Ceará, and Universidade Católica de Brasília are gratefully acknowledged. CAPES provided fellowship funds for LPLL. The authors are indebted with to Professor Dr. Inês Sabioni Resck, Universidade de Brasília, and Professor Dr. Edilberto Rocha Silveira, Universidade Federal do Ceará, for the ${ }^{1} \mathrm{H}(300$ and $500 \mathrm{MHz})$ and ${ }^{13} \mathrm{C}$ (75 and $125 \mathrm{MHz}$ ) NMR spectra data. The authors also want to acknowledge Dr. Carlos Bloch, Jr. and Jorge A.T. Melo, Laboratório de Espectrometria de Massa, EMBRAPA-CENARGEN-DF for HR-ESI-MS of all macrocyclic lactones.

\section{References}

1. Mitchell, J. D.; Mori, S. A. In Memoirs of the New York Botanical Garden, The New York Botanical Garden: New York, 1987, p. 42; Tyman, J. H. P. In Studies in Natural Products Chemistry; Atta-ur-Rahman ed., Elservier Science Publisher: Armsterdam, 1991, p.9.

2. Toyomizu, M.; Okamoto, K.; Ishibashi, T.; Chen, Z.; Nakatsu, T.; Life Sci., 2000, 66, 229; Prithiviraj, B.; Manickam, M.; Singh, V. P.; Ray, A. B.; Can. J. Bot. /Rev. Can. Bot. 1997, 75, 207; Muroi, H.; Kubo, I.; J. Appl. Bacteriol. 1996, 80, 387; Kubo, J.; Lee, J. R.; Kubo, I.; J. Agric. Food Chem. 1999, 47, 533; Kubo, I.; Muroi, H.; Himejima, M.; J. Agric. Food Chem. 1993, 41, 1016.

3. Paramashivappa, R.; Kumar, P. P.; Rao, P. V. S; Rao S. A.; Bioorg. Med. Chem. Lett. 2003, 13, 657; Paramashivappa, R.; Kumar, P. P.; P. Subba Rao, V.; Rao, S. A.; J. Agric. Food 
Chem. 2002, 50, 7709; Elsholy, M. A.; Adawadkar, P. D.; Beniggni, D. A.; Watson, E. S.; Little, T. L., Jr.; J. Med. Chem. 1986, 29, 606; Kiong, L. S.; Tyman, J. H. P.; J. Chem. Soc., Perkin Trans. 1 1981, 1942; Gulati, A. S.; Subba Rao, B. C. S.; Indian J. Chem. 1964, 2, 337.

4. Wang, X.; Porco J. A., Jr.; J. Am. Chem. Soc. 2003, 125, 6040; Coleman, R. S.; Garg, R.; Org. Lett. 2001, 3, 5019; Boyd, M. R.; Farina, C.; Belfiore, P.; Gagliardi, S.; Kim, J. W.; Hayakawa, Y.; Beutler, J. A.; McKee, T. C.; Bowman, B. J.; Bowman, E. J.; J. Pharm. Exp. Therap. 2001, 297, 114; Kim, J. W.; Shin-ya, K.; Furihata, K.; Hayakawa, Y.; Seto, H.; J. Org. Chem. 1999, 64, 153 .

5. Su, Q.; Panek, S.; J. Am. Chem. Soc. 2004, 126, 2425; Hilli, F.; White, J. M.; Rizzacasa, M. A.; Org. Lett. 2004, 6, 1289; Nicolaou, K. C.; Kim, Q. W.; Baati, R.; Chem. Eur. J. 2003, 9, 6177; Bhattacharjee A.; Seguil, O. R.; De Branbander, J. K.; Tetrahedron Lett. 2001, 42, 1217; Kunze, B.; Fansen, R.; Sasse, F.; Hofle, G.; Reichenbach, H.; J. Antibiot. 1998, 51, 1075.

6. Erickson, K.L.; Beutler, J. A.; Cardellina, J. A.; Boyd, M. R.; J. Org. Chem. 1997, 62, 8188. For the synthetic approaches, see: Yadav, J. S.; Srihari, P.; Tetrahedron: Asymmetry 2004, 15, 81; Yang, K. L.; Blackman, B.; Diederich, W.; Flaherty, P. T.; Mossman, C. J.; Roy, S.; Ahn, Y. M.; Georg, G. I.; J. Org. Chem. 2003, 68, 10030; Herb, C.; Maier, M. E.; J. Org. Chem. 2003, 68, 8129; Labrecque, D.; Charron, S.; Rej, R.; Blais, C.; Lamothe, S.; Tetrahedron Lett. 2001, 42, 2645; Furstner, A.; Thiel, O. R.; Blanda, G.; Org. Lett. 2000, 2, 3731.

7. For a recent review, see: Yet, L.; Chem. Rev. 2003, 103, 4283.

8. Cachoux, F.; Ibrahim-Ouali, M.; Santelli, M.; Synlett 2002, 1987; Furstner, A.; Thiel, O. R.; Blanda, G.; Org. Lett. 2000, 2 , 3731; Bracher, F.; Schulte, B.; J. Chem. Soc., Perkin Trans. 1 1996, 2619.

9. Couladouros E. A.; Mihou, A. P.; Bouzas, E. A.; Org. Lett. 2004, 6, 977; Takahashi, T.; Minami, I.; Tsuji, J.; Tetrahedron Lett. 1981, 22, 2651.

10. Bracher, F.; Schulte, B.; Liebigs Ann-Recl. 1997, 1979; Bracher, F.; Schulte, B.; Nat. Prod. Lett. 1995, 7, 65; Takahashi, T.; Ikeda, H.; Tsuji, J.; Helv. Chim. Acta 1977, 60, 3039.
11. Ghisalberti, E. L.; Hockless, D. C. R.; Rowland, C. Y.; Aust. J. Chem. 1993, 46, 571; Ghisalberti, E. L.; Almassi, F.; Skelton, B. W.; Aust. J. Chem. 1994, 47, 1193.

12. Aldridge, D. C.; Galt, S.; Giles, D.; Turner, W. B.; J. Chem. Soc., C 1971, 1623.

13. Lee, K-H.; Hayahi, N.; Okano, M.; Hall, I. H.; Wu, R-Y.; McPhail, A. T.; Phytochemistry 1982, 21, 1119.

14. Furstner, A.; Seidel, G.; Kindler, N.; Tetrahedron 1999, 55, 8215 .

15. Dos Santos, M. L.; de Magalhães, G. C.; J. Braz. Chem. Soc. 1999, 10, 13.

16. Dos Santos, M. L.; de Magalhães, G. C.; Quim. Nova 1993, 16, 534; Carvalho, M. G.; Braz-Filho, R.; Dos Santos, M. L.; de Magalhães, G. C.; J. Braz. Chem. Soc. 1993, 4, 158.

17. Meyer, B. N.; Ferrigni, N. R.; Putnan, J. E.; Jacobsen, L. B.; Nichols, D. E.; McLaughlin, J. L.; Planta Med. 1982, 45, 31.

18. Kiong, L. S.; Tyman, J. H. P.; J. Chem. Soc., Perkin Trans. 1 1981, 1942; Paramashivappa, R.; Kumar, P. P.; Vithayathil, P. J.; Rao, A. S.; J. Agric. Food Chem. 2001, 49, 2548.

19. Yalpani, M.; Tyman, J. H. P.; Phytochemistry 1983, 22, 2263.

20. Mukaiyama, T.; Usui, M.; Saigo, K.; Chem. Lett. 1976, 49.

21. McLaughlin, J.; Chang, C.; Smith, D. In Studies in Natural Products Chemistry, Atta-ur-Rahman ed., Elservier Science Publisher: Armsterdam, 1991, 9.

22. Matthews, R. S.; Free Radical Bio. Med. 1995, 18, 919.

23. Kang, T. H.; Pae, H. O.; Yoo, J. C; Kim, N. Y.; Kim, Y. C.; Ko, G. I.; Chung, H. T.; J. Ethnopharmacol. 2000, 70, 177.

24. Mosmann, T.; J. Immunol. Methods 1983, 65, 55.

25. Alley, M. C.; Uhl, C. B.; Lieber, M. M.; Life Sci. 1982, 31, 3071.

26. Shoemaker, R.; Wolpertdefilippes, M., Kern, D.; Lieber, M.; Miller, W.; Salmon, S.; Simon, R.; Vonhoff, D.; P. Am. Assoc. Canc. Res. 1984, 25, 1292.

27. Pessoa, C.; Silveira, E.R.; Lemos, T.G.L.; Wetmore, L.A.; Moraes, M.O.; Leyva, A.; Phytother. Res. 2000, 14, 187.

28. Jimenez, P. C.; Fortier, S.C.; Lotufo, T. M. C.; Pessoa, C.; Moraes, M. E. A.; Moraes, M. O.; Costa-Lotufo, L. V.; J. Exp. Mar. Biol. Ecol. 2003, 287, 93.

29. Tyman, J. H. P.; Jocobs, N.; J. Chromatogr. 1971, 54, 83.

Received: March 24, 2005

Published on the web: September 22, 2005 